\title{
DETERMINANT FACTOR FOR NET INTEREST MARGIN: A CASE STUDY ON “X” BANK IN SURABAYA MAIN BRANCH
}

\author{
Indriawan Bambang
}

Researcher, Indonesia

\begin{abstract}
The main purpose in business entity, include in Bank is to gain sufficient profit in order to keep continue and develop. This research is to analyze about the effect of Loan to Deposit Ratio, Operating Cost, Non Performing Loan and Interoffice Account (IA) toward Net Interest Margin on PT. Bank X Surabaya Main Branch, by using financial report from year of 2011 until 2015. Analysis Methode which is used to examine the proposed hypothesis is Multiple Regresion Analysis (MRA). This research concluds that both partially and together Loan to Deposit Ratio, Operating Cost, Non Performing Loan and Interoffice Account (IA) has an effect towards Net Interest Margin (NIM) in PT. Bank X Surabaya Main Branch. Variable Loan to Deposit Ratio, Operating Cost and Interoffice Account (IA) has a positive impact to Net Interest Margin, while variable Non Performing Loan has a negative impact to Net Interest Margin. This means that in order to survive and develop, bank needs to increase credit, increase efficiency and manage credit problems through prudence principles.
\end{abstract}

\section{KEY WORDS}

Loan to deposit ratio, operating cost, non performing loan, interoffice account, net interest margin.

Banking is financial institution that has a vital role to the economic stability of a country that can affect to a wider community, where banks are required to have a good performance in maintaining national economy. Because it involves many people, many community it has a systemic impact to an economy, then all banking activities in Indonesia is managed by the government regulation in this case Otoritas Jasa Keuangan (OJK) is a regulator. Supervise is done in order to maintain banks' performance is always in good condition and right, because bank is a financial institution that plays a role in sustain and stabilize national economy.

Banks' performance evaluation is done to keep the banks work professionally and good so that people's trust in banking is increasing and better after monetary crisis issue. Banks are required to conduct self assessment by using Risk approach (Risk-based Bank Rating/RBBR) both in individually or consolidation, with the scope of assessment factors are (1) Risk Profile; (2) Good Corporate Governance (GCG); (3) Profitability (Earnings); and Capital.

Banks ability in gaining a profit, known as Profitability is the most important factor to determine banks' health level. Main purposes from business including banking are to gain sufficient profit to survive and develop.

Measuring for efficiency level and banks' profit is reviewed by looking at the magnitude of Net Interest Margin, that is comparison between net income and the average bank earning assets.

Net Interest Margin (NIM) is a ratio that is used to measure profitability level and banks' efficiency, especially which banks that still rely on income from interest difference.

The net interest is a difference between interest income and interest expense which includes Interoffice Account (IA). The higher NIM achieved by the bank shows the better performance from the bank.

That is the reason why national banking on early 2016 start to targeting NIM in specify number in order to increasing minimal profit compare than the number on year 2015. There are three main factors that influence banks' profitability, that are operational efficiency, asset quality and liquidity. Especially to branch office, profitability level also influenced by Interoffice Account (IA). 
Efficiency is very important for main branch to measure how good and right is the main bank activities to gain sufficient profit. With the minimum operational costs but the result obtained large make the bank looks efficient in managed banks' operational cost, also will work in low interest margin. However, if the operational costs is high so the bank will work hard by setting high interest margin to cover inefficient operational costs.

Asset quality related to productive asset quality which is owned by main bank. Quality measurement indicator on main bank can be seen by ratio NPL (Non Performing Loan). This factor take effect to interest profit, considering if there is a bad credit or even stuck so profit interest also will take effect.

Liquidity is very important because banking product is the third party funds (Deposits) and loans provided (Credits). This factor is related to composition or portfolio from Credits and Deposits, or known as Loan to Deposit Ratio (LDR), used to measure how big the bank in is meet and maintain liquidity also in how big is the income from credit interest.

Loan disbursement is the main activity of the bank, therefore the largest source of bank's main income comes from this activity. The greater distribution of funds in the form of credit than third party funds in a bank brings the consequences the greater risk to be borne by the bank concerned.

The existence of this Interoffice Account (IA) determines whether the branch will earn IA revenue from head office or spend IA cost to head office. This factor affects the net interest income, especially for branches and sub-branches office, given the fund management is still centralized in the head office; the IA factor greatly affects the net interest income of the branch to obtain maximum profit.

Based on internal financial report data from 18 (eighteen) branches of PT. Bank X, the profit in Surabaya main branch almost the same with the profit earned by Tasikmalaya main branch which has a total assets Rp. 278 billion with LDR 205,41\%, even profit from Tangerang main branch which has a total asset Rp. 176 billion with LDR 79,82\% is bigger than Surabaya main branch which has a total asset Rp. 750 billion with LDR 18,94\%.

Based on above financial report data especially about profit in Main Branch of PT. Bank X encourages the study of the effect of Loan to Deposit Ratio (LDR), Operating Cost (OC), Non Performing Loan (NPL) and Interoffice Account (IA) to Net Interest Margin (NIM). This result of this research is expected to give a Head of Main Branch PT. Bank X to improve banks operational performance.

\section{LITERATURE REVIEW}

The theoretical basis that is used as a guideline by the researcher in doing research is Net Interest Margin (NIM) and factors influencing the formation of NIM namely Operating Cost (OC), Loan to Deposit Ratio (LDR), Non Performing Loan (NPL) and Interoffice Account (IA).

Net Interest Margin (NIM). According to Frianto Pandia (2012: 83), Net Interest Margin (NIM) is a profitability ratio that shows comparison between net interest income with the average earning assets owned by the bank, the ratio indicates the ability the bank management in managing its earning assets to generate net interest income. Based on attachment 14 of a Bank Indonesia Circular Letter No. 13/30/DPNP dated 16 December 2011 in the calculation formula for NIM ratio is:

$$
\mathrm{NIM}=\text { Net Interest Income } / \text { Average Productive Assets }
$$

Net interest income (annual) is interest income - interest expense.

Loan to Deposit Ratio (LDR). According to Frianto Pandia (2012: 128), Loan to Deposit Ratio (LDR) is a ratio that states how far the bank has used the depositors' money to lend to its customers. Loan to Deposit Ratio (LDR) is simply a comparison between the loan disbursed and the total collected third party funds. According to Frianto Pandia (2012: 119), formula for Loan to Deposit Ratio (LDR) is: 


$$
\text { LDR }=(\text { Loans Provided } / \text { Third Party Funds }) \times 100 \%
$$

Operating Costs (OC). Operating cost or operational expense is all the sacrifices that are spent by the company to fund the operations of the company in order to achieve the goals to be achieved by the company. According to Frianto Pandia (2012: 20) the operational cost (overhead cost) is the cost of managing the activities and business of the bank, either directly or indirectly affecting the cost of credit, such as human resources cost, the cost of facilities / infrastructure supporting the cost of bank assets, promotion activities, labor costs and operational costs. According to Sharma and Gounder (2011) Operational Costs are defined as the ratio between operating costs and total assets. While according to Islam and Nishiyama (2016) the bank's operational costs include non-interest fees such as overhead, administration fees, maintenance fees and other expenses. Based on some of the above definitions and research results from the journals Nassar, Martinez and Pineda (2014), Sharma and Gounder (2011), Maudos and Guevara (2004) and Islam and Nishiyama (2016) obtained the formula for Operating cost $(\mathrm{OC})$ is:

$$
\mathrm{OC}=\text { Operating expenses } / \text { Total Assets }
$$

Non Performing Loan (NPL). Non Performing Loan is the ratio of comparison between problem loan and total credit. Ratio NPL is used to see how far the bank management managing problem loans, since the higher risk ratio of NPL, the credit quality of the bank is getting worse. Bank Indonesia has set a maximum of $5 \%$ of bank NPLs. Based on attachment 14 of a Bank Indonesia Circular Letter No. 13/30/DPNP dated 16 December 2011 in the calculation formula for NPL are divided into two:

- NPL gross is the ratio of non-performing loans based on the carrying amount of the balance in gross (before deducting allowance for impairment losses) with total credits calculated based on the carrying amount in the balance sheet.

$$
\text { NPL gross }=\text { Non Performing Loan } / \text { Total Credits }
$$

- NPL net is the ratio of non-performing loans based on the net carrying amount of the net balance (after deducting allowance for impairment losses) with total credits calculated based on the carrying amount in the balance sheet.

NPL net $=$ Non Performing Loans - allowance for impairment losses $/$ Total Credits

Interoffice Account (IA). According to Bank Indonesia's Regulation No. 14/15/PBI/2012 Interoffice Account (IA) is a charge arising from inter-office transactions that have not been completed within a certain period of time. According to Septian Dwi Purwanto (2015) Interoffice Account (IA) is an Account used to collect and channel funds in the framework of the calculation of Interoffice Benefits. Intercompany Revenue is an incentive in return for a branch office that has excess funds in fund raising and fund disbursement activities, its implementation is treated as an inter-office transaction, between a branch office with a head office and a branch with a sub-branch.

Based on the definition and components of IA it can be concluded that the ratio of IA calculation:

RAK = Total Balance IA in one month / Total Deposits in one month

The effect of LDR on NIM. The greater the amount of credit is given and the deposit collected by the bank the greater the potential rate of losses faced by the bank, so it needs to be compensated with a large net interest margin rate as well. Thus, the LDR can have a negative effect. According to Fungacova from the research Taufik Ariyanto (2011), from the perspective of economies of scale, the greater the distribution of credit then there should be benefit efficiency caused by the cost per unit for the management and distribution of credit 
portfolio. Thus, the effect of lending to net interest margin may be positive or negative. Based on the results of research conducted by Taufik Ariyanto (2011), LDR has a negative influence on Net Interest Margin (NIM) banking factor in Indonesia. While the results of Islamic studies and Nishiyama (2016) showed that LDR has positive effect on NIM in South Asian countries (Bangladesh, India, Nepal and Pakistan).

Effect of Operating Cost (OC) on NIM. Operating cost is an operational cost which includes interest cost and non interest expense, it can conceptually determine the determination of interest margin to be sold to the public so as to obtain good results for the bank. According to Nassar, Martinez and Pineda (2014) operating costs are the most important determinants of net interest margin, the bank should also be encouraged to improve operational efficiency in order to reduce overhead costs in order to determine interest margins. According to Maudos and Guevara (2004) banks that have a high average operating cost should operate with higher margins to enable them to offset higher transformation costs. Meanwhile, according to Islam and Nishiyama (2016) the principle is that if the operational cost of the bank unit is relatively higher (less efficient), the bank will try to compensate by imposing additional on regular margin. Based on Nassar research, Martinez and Pineda (2014), Sharma and Gounder (2011), Maudos and Guevara (2004) and Islam and Nishiyama (2016) stated that Operating cost has a positive influence on NIM.

The effect of NPL on NIM. The level of influence of credit risk is similar to the principle of the effect of money market interest rate volatility, the higher the level of credit risk faced by the banking, the higher the risk premium rate must be so that Net Interest Margin will be greater, as well as the opposite condition. The risk faced in the event of NPL is that the bank must reserve the elimination fee according to regulatory regulation and this may affect the operational cost incurred. Based on research by Taufik Ariyanto (2011); Nassar, Martinez and Pineda (2014), Sharma and Gounder (2011), and Maudos and Guevara (2004) mentioned that NPL (credit risk) has a positive influence on NIM. While Islam and Nishiyama (2016) mentioned that NPL (credit risk) has a negative influence on NIM.

The effect of IA on NIM. According to Septian Dwi Purwanto (2015), basically every activity in banking, either in conventional bank or in syariah bank, cannot be separated from inter-office activities. Transactions in inter-office activities enable the management of a bank to provide incentives in the form of revenues and expenses for internal bank transactions, especially in terms of providing funds for branch offices that will perform the financing distribution but the branch office has minimal funds. Meanwhile, according to Roy $M$ Manulang (2011) Fund Transfer Pricing (FTP) is a mechanism to calculate net income up to the lowest level in bank organization or based on other criteria such as net income per line of business, product and others. FTP also separates profit from commercial activities (related to customers) and activities related to risk management. FTP can be understood as transfer pricing for bank products that are fund raising activities and loan disbursement and asset \& liability management, where the transfer price is stated at the interest rate. So it can be concluded that Inter-Office Account (IA) is also determine the profit or loss of the Branch where there is an element of interest rates as the basis of selling the price of funds and borrow funds to other branches or headquarters.

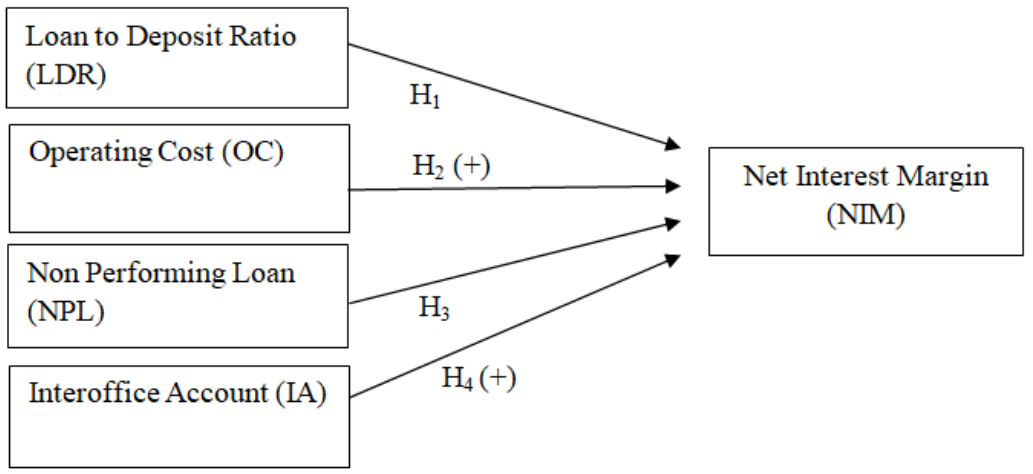

Figure 1 - Theoretical Framework 
Hypothesis:

$\mathrm{H1}$ : Loan to Deposit Ratio (LDR) effect on NIM;

$\mathrm{H} 2$ : Operating cost (OC) positive effect on NIM;

H3: Non Performing Loan (NPL) effect on NIM;

H4: Interoffice Account (RAK) positive effect on NIM;

H5: Loan to Deposit Ratio (LDR), Operating cost (OC), Non Performing Loan (NPL) and Interoffice Account (IA) are affecting NIM.

\section{METHODS OF RESEARCH}

This study uses variables depend on Net Interest Margin and Loan to Deposit Ratio independent variable, Operating Cost, Non Performing Loan, and Interoffice Account. Net Interest Margin (NIM) is the ratio of net interest income divided by the average earning assets. The net interest income calculated is interest income minus annual interest expense. Measurement of NIM variables using the formula:

(1). Loan to Deposit Ratio (LDR) is the ratio of credits extended to third parties in Rupiah and foreign currency, excluding credits to other banks, to depositor funds covering demand deposits, savings deposits and time deposits in Rupiah and foreign currency, excluding interbank funds. Measurement of LDR variables using the formula;

(2). Operating cost (OC) is the ratio of operational cost to total asset, for calculation using previous month's Operating cost (OC) data to Net Interest Margin (NIM) data next month. Measurement of OC variables using the formula;

(3). Non Performing Loan (NPL) is the ratio of nonperforming loans to total loans granted. Measurement of the NPL variable using the formula;

(4). Finally, Interoffice Account (IA) is the ratio of total IA in one month to total Deposits in one month. The measurement of the IA variable uses formula (6).

Population, Sample and Data. This research is a case study research on the main branch of PT. Bank X in Surabaya. The research period chosen as the sample is 2011 to 2015, with consideration to see how big the role of PT. Bank X Surabaya Branch in affecting the value of NIM PT. Bank X nationally before and after the merger between PT. Bank Y with PT. Bank Z in 2014.

In this study the data used is secondary data taken from PT. Bank X Surabaya main branch. The data obtained is the balance sheet data per month during 2011 to 2015 from the bank's internal system.

Data Analysis Technique. Data analysis technique used in this research is Multiple Regression Analysis (MRA) which is multivariate analysis tool used to test the influence of some independent variable (independent variable) to dependent variable (dependent variable). The following concurrent regression research model:

$$
\mathrm{NIM}=\alpha+\beta_{1} \mathrm{LDR}+\beta_{2} \mathrm{OC}+\beta_{3} \mathrm{NPL}+\beta_{4} \mathrm{IA}+\mathrm{e}
$$

\section{RESULTS AND DISCUSSION}

Descriptive Analysis. Descriptive analysis is performed on free variables, namely Loan to Deposit Ratio (LDR), Operating Cost (OC), Non Performing Loan (NPL) and Interoffice Account (IA) and dependent variable ie Net Interest Margin (NIM). Table 1 shows that the Net Interest Margin (NIM) average is 13.96 percent with a standard deviation of 2.22 percent. This represents the monthly NIM of PT. Bank X Surabaya's main branch in 2011 until 2015 is very good, in accordance with the objectives to be achieved by the Management of PT. Bank $X$ Centers of 2016 ie increase NIM above 5.5 percent.

The average Loan to Deposit Ratio (LDR) was 28.16 percent with a standard deviation of 10.23 percent. With the low average LDR of PT. Bank X Surabaya's main branch illustrates the condition of branches with excess liquidity. This is not good in terms of liquidity considering there are excess funds settle and not channeled into productive assets (loans). 
The average value (mean) Operating cost $(\mathrm{OC})$ is 46.06 percent with a standard deviation of 22.93 percent. On average, PT. Bank X Surabaya main branch is quite efficient in terms of operational costs incurred every month from 2011 to 2015. However, judging from the largest deviation standard among all variables, the operational costs incurred each month are unstable.

Table 1 - Descriptive Analysis Variable (\%)

\begin{tabular}{|c|c|c|}
\hline Variable & Mean & Std Deviation \\
\hline NIM & 13,96 & 2,22 \\
\hline LDR & 28,16 & 10,23 \\
\hline OC & 46,06 & 22,93 \\
\hline NPL & 4,14 & 3,48 \\
\hline IA & 73,45 & 11,18 \\
\hline
\end{tabular}

The average Non Performing Loan (NPL) was 4.13 percent with a standard deviation of 3.48 percent. Describes the average problem loans PT. Bank $X$ Surabaya main branch is quite high almost near the limit set by the regulator that is equal to 5 percent. Based on internal data of PT. Bank X Surabaya Main Branch, NPL per month for five years (2011 to 2015) Increase in NPL occurred in February 2013, even NPLs are above 5 percent from May 2013 until December 2015. So, the average NPL value from February 2013 through December 2015 at 6.84 percent and exceeding the 5 percent limit.

The mean value of Interoffice Account (IA) is 73.45 percent with a standard deviation of 11.18 percent. Describes that every month PT. Bank X Surabaya main branch in 2011 to 2015 earns IA interest income from its Head Office and Assisted Branches, in the absence of excess funds deposited and not channeled to productive assets (loans).

Regression Analysis. Multiple regression analysis (MRA) is used to measure how big the influence of each independent variable to NIM. Based on Table 4.2, it can be formulated results from the regression equation as follows:

$$
\mathrm{NIM}=-15,176+0,184 \mathrm{LDR}+0,030 \mathrm{OC}-0,288 \mathrm{NPL}+0,324 \mathrm{IA}+\mathrm{e}
$$

Table 2 - Result of Regression Analysis

\begin{tabular}{|c|c|c|c|c|}
\hline Variable & B & $t$ count & $t$ table & Conclusion \\
\hline (Constant) & $-15,176$ & \multicolumn{3}{|l|}{} \\
\hline LDR & 0,184 & 2,015 & $+/-2,00404$ & Hypothesis Accepted \\
\hline OC & 0,030 & 1,868 & 1,67303 & Hypothesis Accepted \\
\hline NPL & $-0,288$ & $-2,416$ & $+/-2,00404$ & Hypothesis Accepted \\
\hline IA & 0,324 & 3,516 & 1,67303 & Hypothesis Accepted \\
\hline$R^{2}$ & 0,532 & \multicolumn{3}{|l}{0,000} \\
\hline F & 15,614 & Sig. & \\
\hline
\end{tabular}

Table 2 shows that the F-count value is 15.614 larger than the F-table of 2.5400 . The magnitude of the significance value is 0.000 smaller than the alpha of 0.05 . It can be concluded that there is simultaneous influence of loan to deposit ratio, operating cost, nonperforming loan, and inter-office account to net interest margin.

Table 2 also shows the influence of each independent variable, namely loan to deposit ratio, operating cost, non performing loan and inter-office account partially to net interest margin. The test results show that the loan to deposit ratio, operating cost and inter-office accounts have a significant positive effect on net interest margin, while non-performing loan significantly affects negatively to net interest margin.

The results of this study indicate that the LDR variable has a significant positive effect on NIM. This means that the higher percentage of funds disbursed in the form of credit, net interest income is also higher. Credit in banking is a productive asset because it is able to generate the highest profit (interest) compared to other fund placement alternatives. In addition, from the perspective of economies of scale, the greater the credit distribution, there 
are efficiency benefits associated with the cost per unit for the management and disbursement of credit portfolio.

Table 3 presents the average loan interest rate and interest Deposits PT. Bank X Main branch Surabaya for 5 (five) years. This table shows that the interest rate of Deposits with credit interest is big enough, so it can be concluded PT. Bank X Surabaya main branch to increase its NIM is expected to disburse loans from existing deposits. PT. Bank X Surabaya main branch should further increase lending, while maintaining caution in loan disbursement, in order to increase net interest income.

Table 3 - Average Interest Rate Data of Credit \& Deposits, PT. Bank X Surabaya Main Branch 2011 to 2015

\begin{tabular}{|c|c|c|}
\hline Years & Credit Interest & Deposits Interest \\
\hline 2011 & 20,56 & 6,50 \\
\hline 2012 & 19,29 & 5,70 \\
\hline 2013 & 18,34 & 5,97 \\
\hline 2014 & 17,55 & 7,64 \\
\hline 2015 & 16,14 & 7,42 \\
\hline
\end{tabular}

Source: Internal PT. Bank X Cabang Utama Surabaya.

The results of this study indicate that the OC variable has a significant positive effect on NIM. Table 4 presents operational cost information (interest and non-interest expenses) of Surabaya Main Branch for 5 (five) years. This table describes the average that causes a significant increase in operating costs are the components of interest costs, insurance premium costs, labor costs and removal costs. This indicates that the largest component contributed to the increase in operational costs in terms of interest costs. Operating costs are the most important determinants of net interest margin, so banks should also be encouraged to improve operational efficiency in order to lower overhead costs in order to determine the interest margin can be reduced. Banks that have a high average operating cost should operate with higher margins to enable them to offset higher transformation costs.

Table 4 - Operational Cost Data, PT. Bank X Surabaya Main Branch 2011 to 2015

\begin{tabular}{|c|c|c|c|c|c|}
\hline Operational Cost & 2011 & 2012 & 2013 & 2014 & 2015 \\
\hline Interest Cost & 18.244 & 29.009 & 41.603 & 57.833 & 58.657 \\
\hline Premium Cost & 351 & 692 & 1.011 & 1.142 & 1.410 \\
\hline Labor Cost & 1.308 & 2.373 & 3.243 & 4.158 & 5.229 \\
\hline Removal Cost & 650 & 1.605 & 6.710 & 8.438 & 7.733 \\
\hline
\end{tabular}

Source: Internal PT. Bank X Surabaya main branch (in millions).

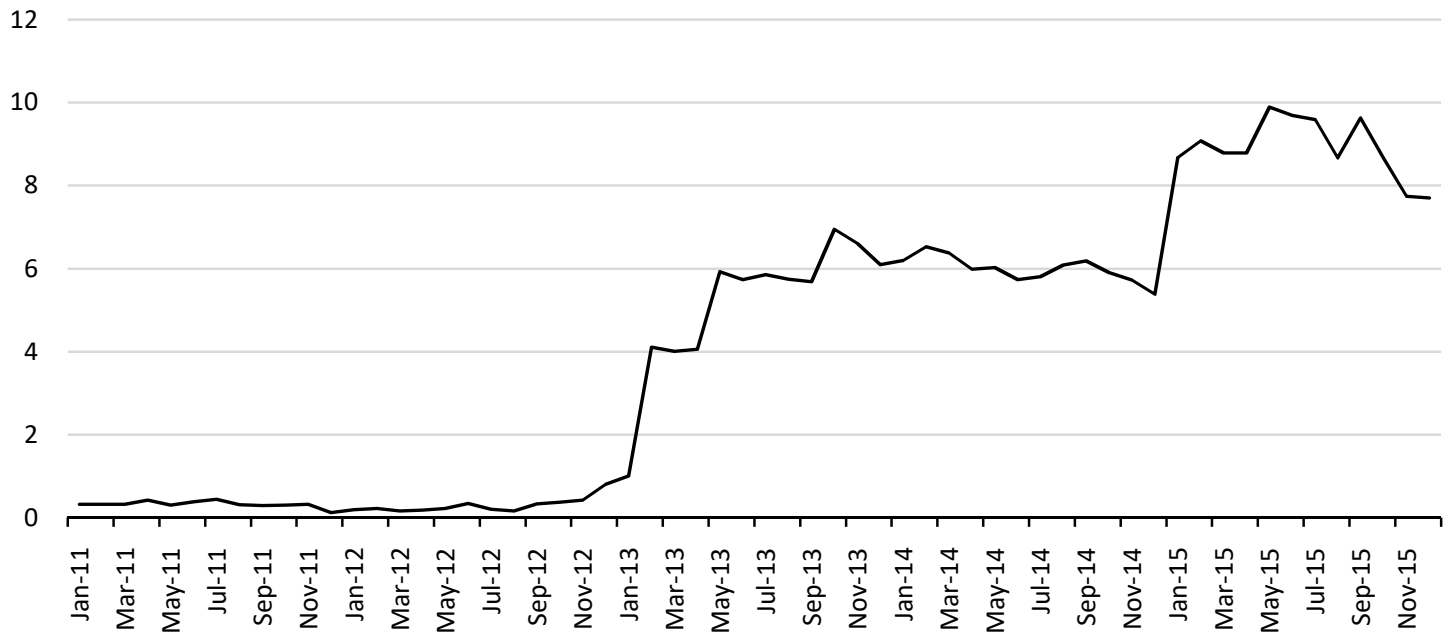

Figure 1 - Increase of NPL per month on 2011 to 2015 
The results of this study indicate that the NPL variable has a significant negative effect on NIM. This indicates that NPLs negatively affect NIM. Figure 1 shows that NPL of PT. Bank $X$ Surabaya main branch obtained the result that the NPL every year has increased to almost 10 percent. From the analysis of existing data through the financial statements, the effect of the increase in NPL is the increase of operational costs of the company due to the removal cost reserves (Earning Asset Backup) from the working capital loan portfolio.

The results of this study indicate that the Interoffice Account (IA) variable has a significant positive effect on NIM. Thus, the higher the IA the greater the NIM. This is possible because of the high differences between IA interest and third party fund interest.

Table 5 - Average interest rate data of Credit, Deposits \& IA interest, PT. Bank X Surabaya Main Branch 2011 to 2015

\begin{tabular}{|c|c|c|c|}
\hline Year & Credit Interest & Deposits Interest & IA Interest \\
\hline 2011 & 20,56 & 6,50 & 10,50 \\
\hline 2012 & 19,29 & 5,70 & 9,90 \\
\hline 2013 & 18,34 & 5,97 & 11,63 \\
\hline 2014 & 17,55 & 7,64 & 14,14 \\
\hline 2015 & 16,14 & 7,42 & 12,42 \\
\hline
\end{tabular}

Source: Internal PT. Bank X Surabaya Main Branch.

Table 5 presents information on average interest rate of Deposits and IA of PT. Bank X Main branch Surabaya for 5 (five) years. This table shows that the interest rate of IA with loan interest is quite large while the interest rate of Deposits with IA interest is also quite large, about 5 percent. The high difference between IA and interest rate Deposits then can encourage PT. Bank X Surabaya main branch feels quite a profit in the form of net interest by placing its funds in inter-office lending. This condition can encourage PT. Bank X Main branch of Surabaya not to distribute funds in the form of credit. Although the difference between loan interest is relatively significant, which is about 4 percent during $2014-2015$, but with quite high NPL of PT. Bank X Branch of Surabaya which amounted to almost 10 percent makes this branch is reluctant to channel funds in the form of credit. PT. Bank $X$ Branch of Surabaya net profit is more advantageous when channeling its funds through interoffice loans which risk of failure does not exist with a net profit of about 5 percent, rather than placing funds in the form of credit which, if not cautious, leads to very high credit problems that erode branch earnings.

\section{CONCLUSION}

The results provide evidence that the loan to deposit ratio, operating cost, nonperforming loans, and inter-office accounts simultaneously affect net interest margin. Partially, the test result shows that the loan to deposit ratio, operating cost and inter-office accounts have a significant positive effect on net interest margin, while non-performing loan significantly affects negatively net interest margin.

This research has some limitations such as (1) incomplete data of credit interest rate, interest rate of Deposits and interest rate of IA PT. Bank X Branch of Surabaya in monthly period during 2011 to 2015, so the writer uses average reference data per year, and (2) $R^{2}$ value equal to $53,2 \%$ shows percentage of Net Interest Margin (NIM) that can be predicted / explained by the independent variables LDR, OC, NPL and IA, while the remaining $46.8 \%$ described other variables that are not examined.

Based on the result of research, there are some implications for PT. Bank X. Firstly, bank management is expected to be able to balance Loan To Deposit Ratio (LDR) so that not too much money settles in Surabaya Main Branch so that it can generate better income. Second, bank management must be careful in expanding credit, especially working capital credit, because the risk is very large if there is bad credit. 


\section{REFERENCES}

1. Ade Sanjaya. Pengertian Biaya Operasional Makalah, Jenis, Perencanaan, Pengawasan, Pada Perusahaan. http://www.landasanteori.com/2015/07/pengertian-biaya-operasionalmakalah.html (diakses tanggal 27 April 2017).

2. Bank Indonesia (2013). Surat Edaran Bank Indonesia nomor 15/1/DPNP tentang Transparansi Informasi Suku Bunga Dasar Kredit. Jakarta Bank Indonesia.

3. Bank Indonesia (2013). Surat Edaran Bank Indonesia No. 15 / 41 / DKMP tentang tata cara pemenuhan Giro Wajib Minimum (GWM) berdasarkan Loan to Deposit Ratio (GWM LDR). Jakarta Bank Indonesia.

4. Bank Indonesia (2011). Surat Edaran Bank Indonesia Nomor 13/30/DPNP tentang Perubahan Ketiga Atas Surat Edaran Bank Indonesia Nomor 3/30/DPNP tanggal 14 Desember 2001 tentang Laporan Keuangan Publikasi Triwulan and Bulanan Bank Umum Serta Laporan Tertentu Yang Disampaikan Kepada Bank Indonesia. Jakarta Bank Indonesia.

5. Bank Indonesia (2012). Peraturan Bank Indonesia Nomor 14/15/PBI/2012 tentang Penilaian Kualitas Aset Bank Umum. Jakarta Bank Indonesia.

6. Frianto Pandia (2012). Manajemen Dana and Kesehatan Bank. Jakarta: Rineka Cipta.

7. Islam, Shahidul.Md. and Nishiyama, Shin-Ichi. (2016). "The determinants of bank net interest margins: A panel evidence from South Asian countries", Research in International Business and Finance. No. 37 (2016) 501-514.

8. Juliansyah Noor (2011). Metodologi Penelitian: Skripsi, Tesis, Disertasi \& Karya Ilmiah. Jakarta: Kencana.

9. Julius R. Latumaerissa (2014). Manajemen Bank Umum. Jakarta: Mitra Wacana Media.

10. Khairunnisa Almadany (2012). "Pengaruh Loan To Deposit Ratio, Biaya Operasional Per Pendapatan Operasional and Net Interest Margin Terhadap Profitabilitas Perusahaan Perbankan Yang Terdaftar Di Bursa Efek Indonesia", Jurnal Riset Akuntansi and Bisnis. 12, Vol. No. 2 (2012) 165-183.

11. Maudos, Joaquin. and Guevara, Juan Fernandez de. (2004). "Factors explaining the interest margin in the banking sectors of the European Union", Journal of Banking \& Finance. No. 28, 2259-2281.

12. Nassar, Koffie. Martinez, Edder. And Pineda, Anabel (2014). "Determinant of bank net ineterest margins in Honduras", International Monetary Fund. No. E43; E44; D43, WP/14/163, 1-26.

13. Nur Indrianto and Bambang Supomo, 2002. Metodologi Penelitian Bisnis Untuk Akuntansi \& Manajemen. Yogyakarta: BPFE.

14. Presiden Republik Indonesia (1998). Undang-Undang Republik Indonesia Nomor 10 Tahun 1998 tentang Perubahan Atas Undang-Undang Nomor 7 Tahun 1992 tentang Perbankan. Jakarta, Presiden Republik Indonesia.

15. Roy M Manullang (2011). Implementasi Sistem Fund Transfer Pricing (FTP) Pada Bank $X$. Tesis Program Studi Magister Management. Fakultas Ekonomi Universitas Indonesia.

16. Sharma, Parmendra. and Gounder, Neelesh (2011). "Determinant of bank net ineterest margins in small island (Developing Economy: Panel Evidence form Fiji)", Griffith Business School. No. 2011-12, ISSN. 1836-8123, 1-14.

17. Septian Dwi Purwanto. Makalah Sistem Pengendalian Manajemen Harga Transfer Dana Pada Bank Syariah. http://septianino.blogspot.co.id/2015/04/makalah-sistempengendalian-manajemen.html (diakses tanggal 16 februari 2017).

18. Teguh Pudjo Muljono (1996). Bank Budgeting, Profit Planning \& Control. Yogyakarta.

19. Taufik Ariyanto (2011). "Faktor Penentu Net Interest Margin Perbankan Indonesia", Finance and Banking Journal. 13, Vol. No. 1, ISSN. 1410-8623, 34-46.

20. Winarni (2011). Analisis Pengaruh Capital Adequacy Ratio, Net Interest Margin, Biaya Operasional Pendapatan Operasional, Loan To Deposit Ratio, SBI and Kurs Terhadap Return On Asset (Studi Komparasi antara Bank Umum Swasta Nasional Devisa and Bank Asing). Masters Thesis Diponegoro University, http://eprints.undip.ac.id/36901 diakses tanggal 30 Maret 2016. 